\title{
Genetic characterisation of microsporidia infecting Indian tasar silkworm, Antheraea mylitta, using morphology and molecular tools
}

\author{
Wazid Hassan and B. Surendra Nath
}

Molecular Pathology Division, Seribiotech Research Laboratory, Central Silk Board Campus, Kodathi, Bangalore, Karnataka, India

\begin{abstract}
The utility of inter simple sequence repeat-PCR (ISSR-PCR) assay in the genetic characterisation and elucidation of the phylogenetic relationship of different microsporidian isolates infecting tropical tasar silkworm, Antheraea mylitta Drury, is demonstrated. A total of 22 different microsporidians collected from the diseased tasar silkworms from Jharkhand state of India were analysed using morphological characters and ISSR-PCR. Observations spores under phase contrast microscope revealed oval to elongate in shape with length ranging from $3.8 \mu \mathrm{m}$ to $5.1 \mu \mathrm{m}$ and width from $2.6 \mu \mathrm{m}$ to $3.3 \mu \mathrm{m}$. All the microsporidian isolates except MIJ-1gC showed gonadal infection and transovarial transmission in infected tasar silkworms. Fourteen out of 20 ISSR primers tested generated reproducible profiles and yielded a total of 281 fragments, of which 273 were polymorphic (97\%). The degree of banding pattern was used to evaluate genetic distances and for phylogenetic analysis. The results demonstrated that ISSR analysis may be a useful and efficient tool for taxonomical grouping and phylogenetic classification of different microsporidians in general.
\end{abstract}

Keywords: genetic marker, genetic relationship, Antheraea mylitta, inter simple sequence repeat-PCR (ISSR-PCR), genetic diversity, geographical distribution

Tropical tasar silkworm Antheraea mylitta Drury (Lepidoptera: Saturnidae) is reared on forest trees, e.g. Terminalia tomentosa Haines, Terminalia arjuna Haines and Shorea robusta Roxb. Tasar silkworm rearing has been a major traditional craft that generates rural employment in various states of India. The rich production potential within the country and steady demand for the tasar fabric in other countries prompts the commercial exploitation of tasar. The main diseases affecting tasar silkworms are microsporidiosis, virosis, bacteriosis and muscardine leading to a crop loss ranging from 40 to $50 \%$ (Singh et al. 2011). Among various diseases that affect $A$. mylitta, the most devastating is caused by the microsporidian Nosema bombycis Nägeli, 1875 since it inflicts severe cocoon crop loss and it is passed on to the next generation transovarially (Chakraborti and Manna 2008).

Microsporidia are a diverse group of spore-forming obligate intracellular eukaryotic parasites with 1300 formally described species in 160 genera approximately (Wittner and Weiss 1999, Keeling 2009). They are unique eukaryotes, because they do not posses centrioles and mitochondrial apparatus, although, nuclei are present in distinct number (Vossbrinck and Woese 1986, Vossbrinck et al. 1987). These parasites infect a wide range of invertebrates and vertebrates including insects, fishes, mammals and protists (Wittner and Weiss 1999, Wasson and Peper 2000, Weiss 2001).

Hatakeyama et al. (2000) identified and characterised a Nosema sp. from A. myitta. During the last two decades, successful development of molecular markers has largely overcome the problems associated with ultrastructural and phenotype-based classification. Random amplified polymorphic DNA (Williams et al. 1990) and inter simple sequence repeats (Zeitkiewicz et al. 1994) were identified as potential molecular marker systems and their use in phylogenetic studies as well as genetic diversity in populations has been documented in a wide variety of organisms (Shivaji et al. 2000, Rao et al. 2005, Nath et al. 2011). Molecular markers have also been used extensively to assess genetic diversity among A. mylitta ecoraces (Vijayan et al. 2005, Dutta et al. 2012).

Simple sequences repeats (SSR), also called microsatellites, are tandem repeats of di-, tri-, tetra- and penta- nucleotides, which are abundant and occur at multiple sites in all prokaryotic and eukaryotic genomes (Field and Wills 1996, Gur-Arie et al. 2000). The important feature of this class of repetitive DNA is its hypervariability, mainly expressed as a variation in the copy number of tandem repeats at a particular locus; it has been proven to be the most powerful genetic marker. Due to their short repeat length and the

Address for correspondence: W. Hassan, Molecular Pathology Division, Seribiotech Research Laboratory, CSB Campus, Carmelram Post, Kodathi, Bangalore-560035, India. Phone: 0091080 28440651; Fax: 0091080 28439597; E-mail: wazidhassan@gmail.com 
limited interaction of individual loci, they can be readily studied through PCR amplifications (Moore et al. 1991).

However, designing SSR primers requires a thorough knowledge of the genome sequences flanking the SSR region and hence can be time-consuming and expensive. Repeat-anchored primers that amplify regions between SSR (referred as inter simple sequence repeats or ISSR) are also proved useful for detecting genetic polymorphisms in microsatellite and intermicrosatellite loci and demonstrated as a novel technique for fingerprinting and differentiating closely related individuals (Zietkiewicz et al. 1994). ISSR-PCR assay has successfully been used to generate molecular markers and to understand genetic diversity and phylogenetic relationship among different microsporidians identified from mulberry silkworms (Rao et al. 2005). The ISSR-PCR strategy is especially attractive because it does not need sequence information for primer synthesis, enjoying the advantage of random markers.

Up to date, there are no reports on molecular marker studies of geographically isolated microsporidian isolates infecting the tropical tasar silkworm, A. mylitta, with special reference to vast geographical forest areas in different districts of Jharkhand State, India. In this backdrop, the present study was undertaken to establish genetic diversity and phylogenetic relationship among 22 microsporidian isolates infecting non-mulberry silkworm, A. mylitta using ISSR-PCR.

\section{MATERIALS AND METHODS}

\section{Origin of microsporidian spores and purification}

Twenty three microsporidian isolates (22 from Antheraea mylitta and one from Bombyx mori Linnaeus) were originally collected from infected $A$. mylitta silkmoths through a survey carried out during 2010 to 2013 in 22 localities belonging to nine geographic regions covering different traditional tasar culture reserved forest areas in the districts of Giridih, Deoghar, Dumka, Dhanbad, Kharshawan, Chaibasha, West-Singhbhum, East-Singhbhum and Ranchi in Jharkhand State, India (Fig. 1, Table 1). The microsporidian spores were isolated from infected tasar silkmoths by maceration and suspended in $0.85 \% \mathrm{NaCl}$ followed by filtration through cheese cloth and centrifugation at $3500 \mathrm{r} / \mathrm{min}$ for $10 \mathrm{~min}$. The spore pellet obtained was purified by Percoll gradient centrifugation (Undeen and Alger 1971). Each of the purified microsporidian isolates was maintained in vivo in isolation in A. mylitta, through per oral inoculation and designated as presented in Table 1 including the reference strain from Bombyx mori, which was designated as NIK-1s_mys. The details of microsporidian isolates, places of collection, host, shape and size are provided in Table 1.

\section{Spore morphology}

The morphology of purified spores was observed using phase contrast microscope (PCM; Carl Zeiss-AXIO, Hamburg, Germany) and their length and width were measured according to the method of Undeen and Vávra (1997). Fresh spores were spread in water agar on glass micro-slides and measured using an ocular micrometer under PCM and all the measurements presented

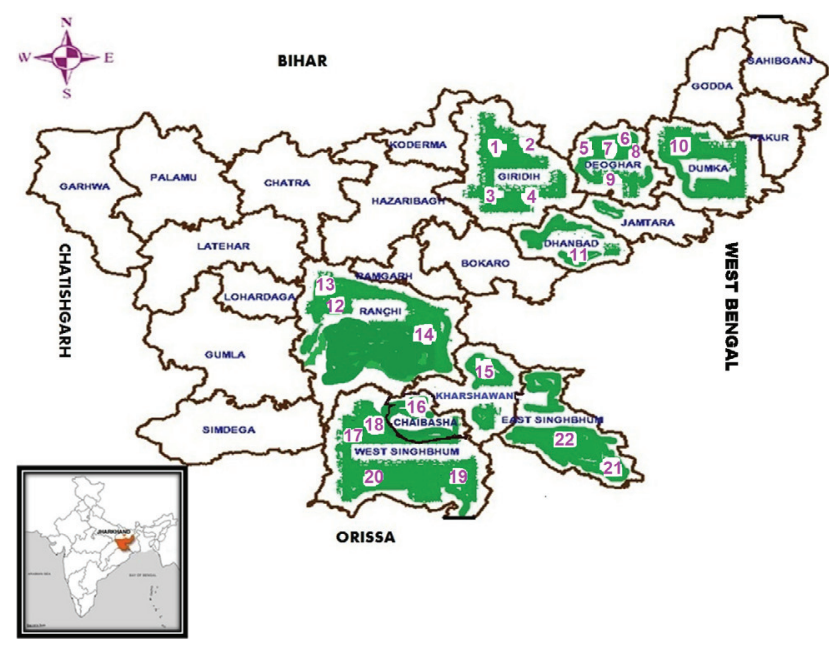

Fig. 1. Map of Jharkhand State, India, showing the distribution of tropical tasar, Antheraea mylitta, in nine geographical forest areas.

are in micrometers as mean values of 12 individual observations (Table 1).

\section{Mode of transmission}

To determine mode of transmission of microsporidian isolates studied, third-instar tasar silkworms were divided into three batches each containing 25 larvae. Each batch was inoculated per orally with $1 \times 10^{5}$ spores $/ \mathrm{ml}$ and the larvae were reared under standard conditions. The tasar silk cocoons obtained were preserved at room temperature till moth emergence. After moth eclosion, mating was allowed for $24 \mathrm{~h}$ and gravid female moths were used for oviposition for $72 \mathrm{~h}$. After oviposition, female moths and their ovaries were homogenised individually and examined for the presence of spores by PCM. The eggs collected from infected moths were surface disinfected with $2 \%$ formaldehyde. Twenty individual eggs laid by each infected female moth were crushed and examined for microsporidian spores at every $48 \mathrm{~h}$ interval of embryonic development i.e. on day $2,4,6,8,10$ and 12 .

\section{DNA extraction}

Genomic DNA was extracted from the sporoplasm discharged from spores using the glass bead method described by Undeen and Cockburn (1989). DNA concentration and quality was determined by spectrophotometry at $260 \mathrm{~nm}$ and $280 \mathrm{~nm}$ and on $0.8 \%$ agarose gel, using a known quantity of $\lambda \mathrm{DNA}(10 \mathrm{ng} / \mu \mathrm{l})$ as a standard before use in subsequent PCRs. The possibility of host DNA contamination was ascertained using insect mitochondrial primers. A working solution of DNA (10 $\mathrm{ng} / \mu \mathrm{l})$ was prepared in sterile autoclaved double distilled water.

\section{PCR amplification of DNA with ISSR primers}

Twenty ISSR primers from primer set 9 (Biotechnology Laboratory, University of British Columbia, Vancouver, Canada) were tested for PCR amplification following the protocol of $\mathrm{Zi}$ etkiewicz et al. (1994) with minor modifications. Of these, 14 primers (11 di-, 2 tri- and 1 pentanucleotides), mostly 15 to 18 mers which were high polymorphic and reproducible observa- 
Table 1. Details of the twenty three microsporidian isolates and reference strain: their place of collection, host and morphology.

\begin{tabular}{|c|c|c|c|c|c|c|c|}
\hline \multirow{2}{*}{$\begin{array}{l}\text { Sl. } \\
\text { No. }\end{array}$} & \multirow{2}{*}{$\begin{array}{l}\text { Name of } \\
\text { isolates }\end{array}$} & \multirow[b]{2}{*}{ Host } & \multirow{2}{*}{$\begin{array}{l}\text { Place of collection (forest area/village), district } \\
\text { Latitude; longitude; elevation }\end{array}$} & \multirow{2}{*}{$\begin{array}{l}\text { Spore } \\
\text { shape }\end{array}$} & \multicolumn{2}{|c|}{ Spore size $(\mu \mathrm{m})$} & \multirow{2}{*}{$\begin{array}{l}\text { Mode of } \\
\text { transmis- } \\
\text { sion }\end{array}$} \\
\hline & & & & & Length & Width & \\
\hline 1 & MIJ-1sG & $\begin{array}{l}\text { Antheraea mylitta } \\
\text { Drury }\end{array}$ & $\begin{array}{l}\text { Sidwasingha forest area, Giridih, Jharkhand, India } \\
24^{\circ} 10^{\prime} 47.07^{\prime \prime N} ; 86^{\circ} 18^{\prime} 85.03 \mathrm{E} ; 301\end{array}$ & EO & $4.8 \pm 0.1$ & $2.9 \pm 0.01$ & $\mathrm{PO}, \mathrm{TO}$ \\
\hline 2 & MIJ-2bG & Antheraea mylitta & $\begin{array}{l}\text { Bariarpur forest area, Giridih, Jharkhand, India } 24^{\circ} 10^{\prime} 47.07 \mathrm{~N} \text {; } \\
86^{\circ} 18^{\prime} 85.03 \mathrm{E} ; 301\end{array}$ & EO & $4.7 \pm 0.1$ & $2.8 \pm 0.1$ & $\mathrm{PO}, \mathrm{TO}$ \\
\hline 3 & MIJ-3gG & Antheraea mylitta & $\begin{array}{l}\text { Gaganpur forest area, Giridih, Jharkhand, India } 24^{\circ} 10^{\prime} 47.07 \mathrm{~N} \text {; } \\
86^{\circ} 18^{\prime} 85.03 \mathrm{E} ; 301\end{array}$ & EO & $3.8 \pm 0.2$ & $2.6 \pm 0.0$ & $\mathrm{PO}, \mathrm{TO}$ \\
\hline 4 & MIJ-4mG & Antheraea mylitta & $\begin{array}{l}\text { Manjhaltal forest area, Giridih, Jharkhand, India } \\
24^{\circ} 10^{\prime} 47.07 \mathrm{~N} ; 86^{\circ} 18^{\prime} 85.03 \mathrm{E} ; 301\end{array}$ & EO & $4.9 \pm 0.1$ & $2.7 \pm 0.0$ & $\mathrm{PO}, \mathrm{TO}$ \\
\hline 5 & MIJ-1jD & Antheraea mylitta & $\begin{array}{l}\text { Jitpur forest area, Deoghar, Jharkhand, India } 24^{\circ} 28^{\prime} 49.88 \mathrm{~N} \text {; } \\
86^{\circ} 42^{\prime} 0.00 \mathrm{E} ; 250\end{array}$ & $\mathrm{EO}$ & $4.4 \pm 0.1$ & $2.9 \pm 0.0$ & $\mathrm{PO}, \mathrm{TO}$ \\
\hline 6 & MIJ-2pD & Antheraea mylitta & $\begin{array}{l}\text { Pindari forest area, Deoghar, Jharkhand, India } 24^{\circ} 28^{\prime} 49.88 \mathrm{~N} \text {; } \\
86^{\circ} 42^{\prime} 0.00 \mathrm{E} ; 250\end{array}$ & $\mathrm{EO}$ & & & $\mathrm{PO}, \mathrm{TO}$ \\
\hline 7 & MIJ-3sD & Antheraea mylitta & $\begin{array}{l}\text { Sarsota forest area, Deoghar, Jharkhand, India } 24^{\circ} 28^{\prime} 49.88 \mathrm{~N} \text {; } \\
86^{\circ} 42^{\prime} 0.00 \mathrm{E} ; 250\end{array}$ & $\mathrm{EO}$ & $4.9 \pm 0.1$ & & $\mathrm{PO}, \mathrm{TO}$ \\
\hline 8 & MIJ-4cD & Antheraea mylitta & $\begin{array}{l}\text { Chechai forest area, Deoghar, Jharkhand, India } 24^{\circ} 28^{\prime} 49.88 \mathrm{~N} \text {; } \\
86^{\circ} 42^{\prime} 0.00 \mathrm{E} ; 250\end{array}$ & EO & & $2.6 \pm 0.0$ & $\mathrm{PO}, \mathrm{TO}$ \\
\hline 9 & MIJ-5mD & Antheraea mylitta & $\begin{array}{l}\text { Madhopur forest area, Deoghar, Jharkhand, India } \\
24^{\circ} 28^{\prime} 49.88 \mathrm{~N} ; 86^{\circ} 42^{\prime} 0.00 \mathrm{E} ; 250\end{array}$ & $\mathrm{EO}$ & & & $\mathrm{PO}, \mathrm{TO}$ \\
\hline 10 & MIJ-1kDm & Antheraea mylitta & $\begin{array}{l}\text { Katikund forest area, Dumka, Jharkhand, India } 24^{\circ} 16^{\prime} 0.12 \mathrm{~N} \text {; } \\
87^{\circ} 15^{\prime} 00.0 \mathrm{E} ; 152\end{array}$ & $\mathrm{O}$ & & & $\mathrm{PO}, \mathrm{TO}$ \\
\hline 11 & MIJ-1gDn & Antheraea mylitta & $\begin{array}{l}\text { Govindpur forest area, Dhanbad, Jharkhand, India } \\
23^{\circ} 47^{\prime} 44.35 \mathrm{~N} ; 86^{\circ} 25^{\prime} 49.39 \mathrm{E} ; 246\end{array}$ & $\mathrm{EO}$ & & & $\mathrm{PO}, \mathrm{TO}$ \\
\hline 12 & MIJ-1bR & Antheraea mylitta & $\begin{array}{l}\text { Bero forest area, Ranchi, Jhar } \\
23^{\circ} 20^{\prime} 38.76 \mathrm{~N} ; 85^{\circ} 18^{\prime} 34.42 \mathrm{E} ;\end{array}$ & $\mathrm{EO}$ & & & $\mathrm{PO}, \mathrm{TO}$ \\
\hline 13 & MIJ-2pR & Antheraea mylitta & $\begin{array}{l}\text { Piska nagri forest area, Ranchi, Jharkhand, India } \\
23^{\circ} 20^{\prime} 38.76 \mathrm{~N} ; 85^{\circ} 18^{\prime} 34.42 \mathrm{E} ; 644\end{array}$ & EO & & & $\mathrm{PO}, \mathrm{TO}$ \\
\hline 14 & MIJ-3rR & Antheraea mylitta & $\begin{array}{l}\text { Ratu forest area, Ranchi, Jharkhand, India } \\
23^{\circ} 20^{\prime} 38.76 \mathrm{~N} ; 85^{\circ} 18^{\prime} 34.42 \mathrm{E} ; 644\end{array}$ & $\mathrm{EO}$ & & & $\mathrm{PO}, \mathrm{TO}$ \\
\hline 15 & MIJ-1kK & Antheraea mylitta & $\begin{array}{l}\text { Kuchai forest area, Kharshawan, Jharkhand, India } \\
22^{\circ} 46^{\prime} 58.70 \mathrm{~N} ; 85^{\circ} 493211 \mathrm{E} ; 212\end{array}$ & $\mathrm{EO}$ & $4.9 \pm 0.1$ & & $\mathrm{PO}, \mathrm{TO}$ \\
\hline 16 & MIJ-1gC & Antheraea mylitta & $\begin{array}{l}\text { Hatramaria forest area, Chaibasha, Jharkhand, India } \\
22^{\circ} 32^{\prime} 57.26 \mathrm{~N} ; 85^{\circ} 48^{\prime} 3003 \mathrm{E} ; 232\end{array}$ & EO & & $3.1 \pm 0.6$ & PO \\
\hline 17 & MIJ-1cWS & Antheraea mylitta & $\begin{array}{l}\text { Chakadharpur forest area, West Singhbhum, Jharkhand, India } \\
22^{\circ} 27^{\prime} 45.13 \mathrm{~N} ; 85^{\circ} 31^{\prime} 12.09 \mathrm{E} ; 380\end{array}$ & EO & & & $\mathrm{PO}, \mathrm{TO}$ \\
\hline 18 & MIJ-2mWS & Antheraea mylitta & $\begin{array}{l}\text { Majhgaon forest area, West Singhbhum, Jharkhand, India } \\
22^{\circ} 27^{\prime} 45.13 \mathrm{~N} ; 85^{\circ} 31^{\prime} 12.09 \mathrm{E} ; 380\end{array}$ & $\mathrm{EO}$ & $4.7 \pm 0.7$ & $3.2 \pm 0.0$ & $\mathrm{PO}, \mathrm{TO}$ \\
\hline 19 & MIJ-3gWS & Antheraea mylitta & $\begin{array}{l}\text { Goelkera forest area, West Singhbhum, Jharkhand, India } \\
22^{\circ} 27^{\prime} 45.13 \mathrm{~N} ; 85^{\circ} 31^{\prime} 12.09 \mathrm{E} ; 380\end{array}$ & $\mathrm{EO}$ & $4.5 \pm 0.3$ & $2.8 \pm 0.3$ & $\mathrm{PO}, \mathrm{TO}$ \\
\hline 20 & MIJ-4nWS & Antheraea mylitta & $\begin{array}{l}\text { Namundi forest area, West Singhbhum, Jharkhand, India } \\
22^{\circ} 27^{\prime} 45.13 \mathrm{~N} ; 85^{\circ} 31^{\prime} 12.09 \mathrm{E} ; 380\end{array}$ & $\mathrm{EO}$ & & & $\mathrm{PO}, \mathrm{TO}$ \\
\hline 21 & MIJ-1cES & Antheraea mylitta & $\begin{array}{l}\text { Chakulia forest area, East Singhbhum, Jharkhand, India } \\
23^{\circ} 4{ }^{\prime} 27.79 \mathrm{~N} ; 86^{\circ} 49^{\prime} 2.58 \mathrm{E} ; 150\end{array}$ & $\mathrm{EO}$ & $4.9 \pm 0.6$ & $2.9 \pm 0.1$ & $\mathrm{PO}, \mathrm{TO}$ \\
\hline 22 & MIJ-2dES & Antheraea mylitta & $\begin{array}{l}\text { Dhumaria forest area, East Singhbhum, Jharkhand, India } \\
23^{\circ} 4^{\prime} 27.79 \mathrm{~N} ; 86^{\circ} 49^{\prime} 2.58 \mathrm{E} ; 150\end{array}$ & $\mathrm{EO}$ & $4.1 \pm 0.1$ & $2.8 \pm 0.2$ & $\mathrm{PO}, \mathrm{TO}$ \\
\hline 23 & NIK-1s_mys & $\begin{array}{l}\text { Bombyx mori } \\
\text { Linnaeus }\end{array}$ & $\begin{array}{l}\text { CSR\&TI, Mysore, Mysore, Karnataka, India } \\
12^{\circ} 17^{\prime} 44.9154 \mathrm{~N} ; 76^{\circ} 38^{\prime} 21.7716 \mathrm{E} ; 770\end{array}$ & $\mathrm{O}$ & & & $\mathrm{PO}, \mathrm{TO}$ \\
\hline
\end{tabular}

Sl. No. - isolate number; MIJ - Microsporidia India Jharkhand; NIK - Nosema India Karnataka; CSR\&TI - Central Sericulture Research and Training Institute; $\mathrm{EO}$ - elongated oval; O - oval; $\mathrm{PO}$ - peroral; $\mathrm{TO}$ - transovarial.

tions, were used for PCR amplification (Table 2). The PCR amplification was carried out in $20 \mu$ of reaction volume, containing $1 \times$ PCR buffer, $30 \mathrm{ng}$ of template DNA, $200 \mu \mathrm{M}$ of each dNTP's, $2.5 \mathrm{mM} \mathrm{MgCl}, 100 \mathrm{pM}$ of a single primer and $1 \mathrm{U}$ of Taq DNA polymerase. The samples were amplified on a DNA thermal cycler (MJ Research Inc., Watertown, MS, USA) with an initial denaturation at $94^{\circ} \mathrm{C}$ for 2 min followed by 35 cycles of $30 \mathrm{~s}$ denaturation at $94^{\circ} \mathrm{C}, 30 \mathrm{~s}$ annealing at $50^{\circ} \mathrm{C}$ and a $2 \mathrm{~min}$ extension at $72^{\circ} \mathrm{C}$ before a final extension of $10 \mathrm{~min}$ at $72^{\circ} \mathrm{C}$ and subsequent cooling at $4^{\circ} \mathrm{C}$. The ISSR amplification PCR products were mixed with bromophenol blue gel loading dye, size fractionated by electrophoresis on $2.0 \%$ agarose gel (Promega Corporation, Madison, WI, USA) in $1 \times$ Tris-borate-EDTA buffer ( $89 \mathrm{mM}$ Tris, $89 \mathrm{mM}$ Boric acid, 2mM EDTA, pH 8.0) and the gels were stained with ethidium bromide $(0.5 \mu \mathrm{g} / \mathrm{ml})$ for $30 \mathrm{~min}$ (Sambrook et al. 1989). A standard molecular weight marker (Thermo Scientific, Wilmington, DE, USA) was used in each electrophoretic run and the UV-transilluminated gels were photographed using Gel Documentation System (Syngene Corporation, Cambridge, UK). Three replicate experiments were carried out to verify the reproducibility of the markers.

\section{Molecular data analysis}

Interpretation of patterns was based on the presence or absence of unequivocally reproducible amplified bands and their size. ISSR markers were scored according to the presence (1) or absence ( 0 ) of a band across twenty three isolates of microsporidians; each primer was scored separately. The scoring was repeated three times and only the reproducible conspicuous bands were included in the analysis. The total number of fragments amplified, the number of polymorphic fragments scored and the percentage of polymorphic bands were recorded. The NTSYS-pc version 2.11T computer program (Applied Biostatistics, Setauket, NY, USA) was used for genetic distance analysis. 
Table 2. The nucleotide sequences of the primers, number of amplified fragments, fragment size and number of polymorphic fragments scored using ISSR profiles of 23 microsporidians DNA in ISSR-PCR.

\begin{tabular}{|c|c|c|c|c|c|}
\hline No. & ISSR & Nucleotide sequence $\left(5^{\prime} \rightarrow 3^{\prime}\right)$ & $\begin{array}{l}\text { No. } \\
\text { Amp }\end{array}$ & $\begin{array}{l}\text { Fragment } \\
\text { size range } \\
\text { (bp) }\end{array}$ & $\begin{array}{l}\text { No. } \\
\text { Poly }\end{array}$ \\
\hline 1 & 812 & GAGAGAGAGAGAGAGAA & 21 & $400-2800$ & 21 \\
\hline 2 & 816 & CACACACACACACACAT & 19 & $350-3500$ & 19 \\
\hline 3 & 817 & CACACACACACACACAA & 21 & $500-3800$ & 21 \\
\hline 4 & 818 & CACACACACACACACAG & 19 & $400-3500$ & 19 \\
\hline 5 & 825 & ACACACACACACACACT & 18 & $350-3600$ & 18 \\
\hline 6 & 826 & ACACACACACACACACC & 20 & $350-3800$ & 18 \\
\hline 7 & 827 & ACACACACACACACACG & 18 & $300-4000$ & 17 \\
\hline 8 & 834 & AGAGAGAGAGAGAGAGYT & 21 & $450-3000$ & 20 \\
\hline 9 & 842 & GAGAGAGAGAGAGAGAYG & 19 & $400-3300$ & 18 \\
\hline 10 & 855 & ACACACACACACACACYT & 21 & $600-2300$ & 20 \\
\hline 11 & 856 & ACACACACACACACACYA & 20 & $500-2500$ & 19 \\
\hline 12 & 862 & AGCAGCAGCAGCAGCAGC & 19 & $550-3000$ & 19 \\
\hline 13 & 864 & ATGATGATGATGATGATG & 18 & $600-5000$ & 17 \\
\hline 14 & 881 & GGGTGGGGTGGGGTG & 27 & $700-4500$ & 27 \\
\hline & & & 281 & & 273 \\
\hline
\end{tabular}

ISSR - ISSR primers identification; No. Amp - No. of fragments amplified; No. Poly - No. of polymorphic fragments scored.

The data were analysed using SIMQUAL ( similarity for qualitative data) method to generate genetic distance values among different microsporidian isolates using Dice coefficients (Dice 1945) $\left[S=2 N_{a b} /\left(2 N_{a b}+N_{a}+N_{b}\right)\right.$, where $N_{a b}$ is the number of bands common to lanes $a$ and $b, N_{a}$ is the total number of bands present in $a$ and $N_{b}$ is the total number of bands in lane $b$ ] (Nei and $\mathrm{Li}$ 1979). The Dice similarity coefficients were then used to construct a dendrogram using the unweighted pair group method with arithmetic averages (UPGMA) employing the SAHN (sequential, agglomerative, hierarchical and nested clustering) module. Bootstrapping with 1000 replications was performed using the WINBOOT software to evaluate robustness of the obtained UPGMA-based dendrogram and their confidence limits (Yap and Nelson 1996). In order to further test the genetic variability, multidimensional scaling of the ISSR data was carried out using the ALSCAL algorithm (SPSS Inc., Chicago, IL, USA). In this method a dissimilarity matrix was created using Euclidean distance and the same was used for the classical Young-Householder multidimensional scaling procedure (Young et al. 1984, Young and Harris 1990)

\section{RESULTS}

\section{Spore morphology}

The different microsporidian isolates identified from diseased Antheraea mylitta (Table 1) were characterised using spore morphology. The mature spores of different microsporidians varied in shape from oval to elongate, measuring 3.8-5.1 $\mu \mathrm{m}$ in length and 2.6-3.3 $\mu \mathrm{m}$ in width (Table 1). NIK-1s_mys, reference strain was oval in shape measuring $3.8 \mu \mathrm{m}$ in length and $2.6 \mu \mathrm{m}$ in width (Table 1).

\section{Mode of transmission}

Out of the 23 microsporidian isolates, only MIJ-1gC did not infect the embryos and was also not transmitted through eggs, indicating non-existence of transovarial transmission and adoption of a horizontal transmission strategy. There was a steady increase in spore multiplication from day 4 to day 12 of embryonic development.

\section{Genetic variability revealed by the ISSR markers}

Genomic DNA from 23 different microsporidian isolates including reference strain was used to generate ISSR-PCR amplification patterns by testing them using 20 ISSR primers. Of the 20 primers, 14 produced good amplification products and were chosen for ISSR analysis. The remaining primers either did not produce amplification products or produced amplified products that were not scorable. A majority of the primers (11) annealed to dinucleotide repeats, while two annealed to tri- and one to penta-nucleotide repeats. Considerable polymorphism was detected with all 14 ISSR primers. A total of 281 fragments were scored from the 14 ISSR primers, out of which 273 were polymorphic (97\%) (Table 2). The ISSR-PCR amplified product profile generated with ISSR-881 primer shown in Fig. 2 clearly indicates the extent of polymorphism among the different microsporidian isolates.

The total number of ISSR markers varied in different isolates with different primers. Some of the bands were common to all isolates, whereas the rest was present only in specific isolates. All 23 microsporidian isolates had different ISSR profiles with the size of the amplified fragments ranging from 300 to $5000 \mathrm{bp}$ (Table 2). The ISSRPCR fingerprinting patterns of the 23 microsporidian isolates with various ISSR primers was used to calculate genetic distance values with Dice (1945) similarity coefficient method. The relationship among the 23 microsporidian isolates, as revealed by genetic similarity calculated from ISSR data, varied from 0.154 to 0.941 (Table 3), suggesting significant variability among them. The lowest value of Dice similarity coefficient (0.154) was found between the MIJ-1bR and MIJ-1kDm isolates collected from Ranchi and Dumka. The highest similarity coefficient (0.941) was found between MIJ-1kK and MIJ-2pR collected from Kharshawan and Ranchi (Table 3).

The genetic similarity values were used for constructing the dendrogram using the un-weighted pair group method with arithmetic averages (UPGMA) method (Fig. 3). The dendrogram grouped 23 microsporidian isolates into two major (A and B) and two minor (C and D) clusters, whereas one was an outlier. Cluster A included seven isolates: MIJ-1sG, MIJ-4mG, MIJ-1bR, MIJ-1gDn, MIJ-2pR, MIJ-1kK and MIJ-3rR, collected from Giridih, Ranchi, Dhanbad and Kharshawan (Fig. 3). Cluster B consisted of 11 isolates, namely MIJ-1jD, MIJ-3sD, MIJ-2pD, MIJ-4cD, MIJ-5mD, MIJ-2dES, MIJ-1cES, MIJ-3gWS, MIJ-4nWS, MIJ-2mWS and MIJ-1cWS, collected from Deoghar, East Shingbhum and West Singhbhum. Cluster $\mathrm{C}$ contained two isolates from Giridih (MIJ-2bG and MIJ-3gG) and cluster D also contained two isolates: MIJ$1 \mathrm{kDm}$ and NIK-1s mys from Dumka and Mysore. The isolate MIJ-1gC collected from Chaibasha was found to be very distant from all the other microsporidians including reference strain, NIK-1s_mys (Fig. 3), indicating that it is a divergent species. 


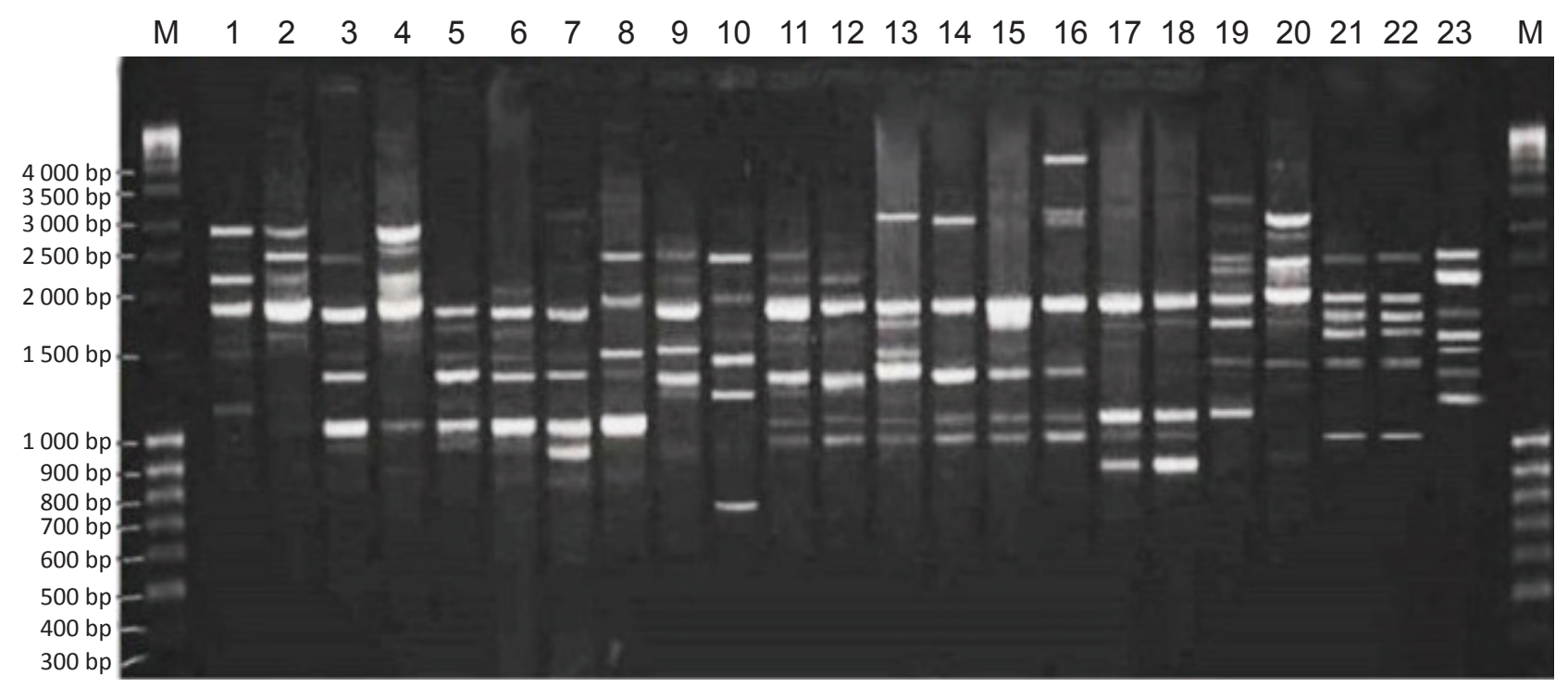

Fig. 2. Inter simple sequence repeat (ISSR) banding profiles obtained on $2.0 \%$ agarose gel for the 23 microsporidian isolates with the primer ISSR-881. For the details on 1-23 microsporidian isolates, see Table 1. Abbreviations: M - molecular size marker.

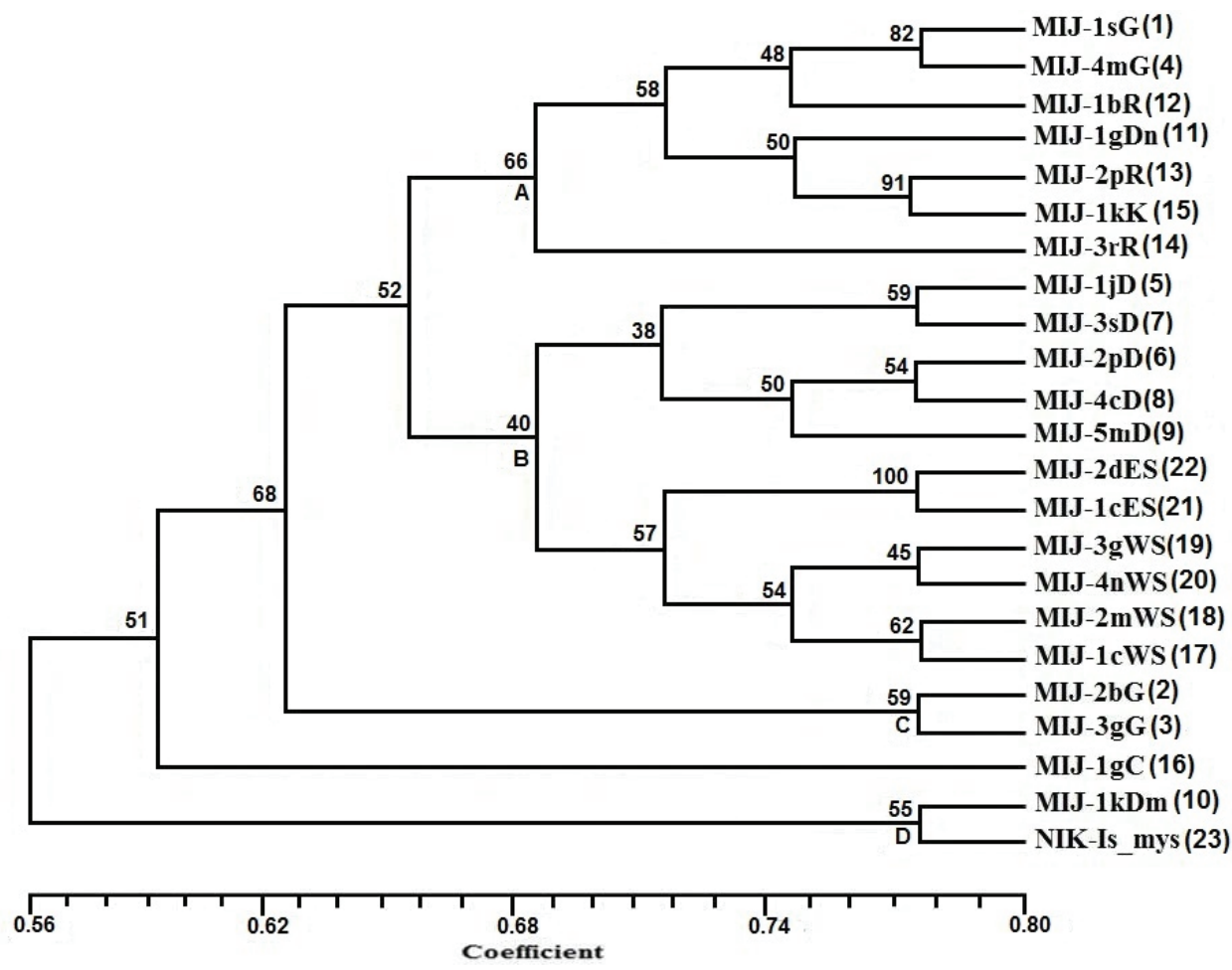

Fig. 3. Dendrogram showing genetic relationships among 23 microsporidian isolates identified from Antheraea mylitta using UPGMA method. Numbers on each node indicate bootstrap values.

\section{Two dimensional distribution of microsporidians as revealed by ALSCAL method.}

The two-dimensional scaling of ISSR data using ALSCAL algorithm based on Euclidean distance matrix has clearly delineated the identified microsporidians from each other as well as from the reference strain, NIK-1s_mys (Fig. 4). Of the 22 microsporidian isolates from A. mylitta, MIJ-1kDm was closer to NIK-1s_mys, indicating that MIJ$1 \mathrm{kDm}$ is similar to the reference strain and the remaining 21 isolates, which differed from each other and from ref- erence strain, could be different species. The grouping of different microsporidians based on Euclidean distance matrix is very similar to that observed in the UPGMA based dendrogram (Fig. 3).

\section{DISCUSSION}

The different microsporidian isolates identified from diseased Antheraea mylitta (Table 1) were characterised using spore morphology and ISSR-PCR. Spores of reference strain, NIK-1s_mys was observed to be similar to the 


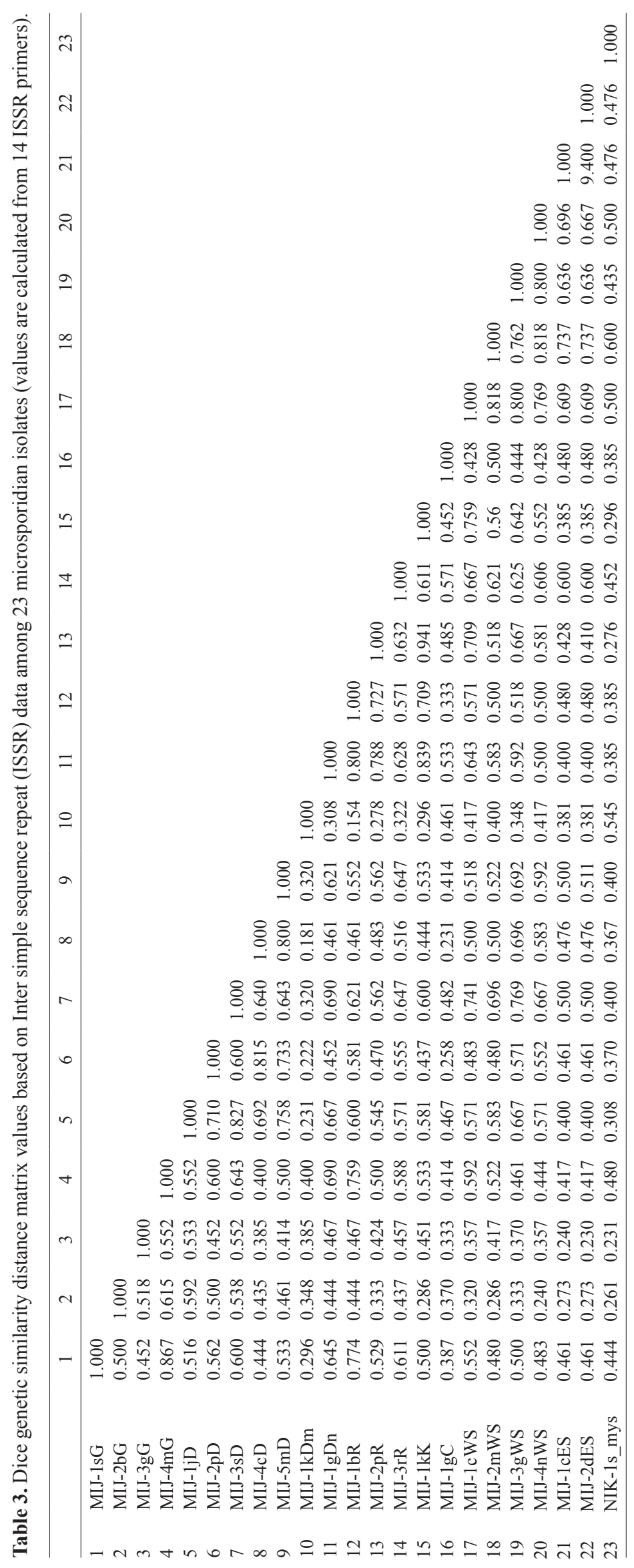




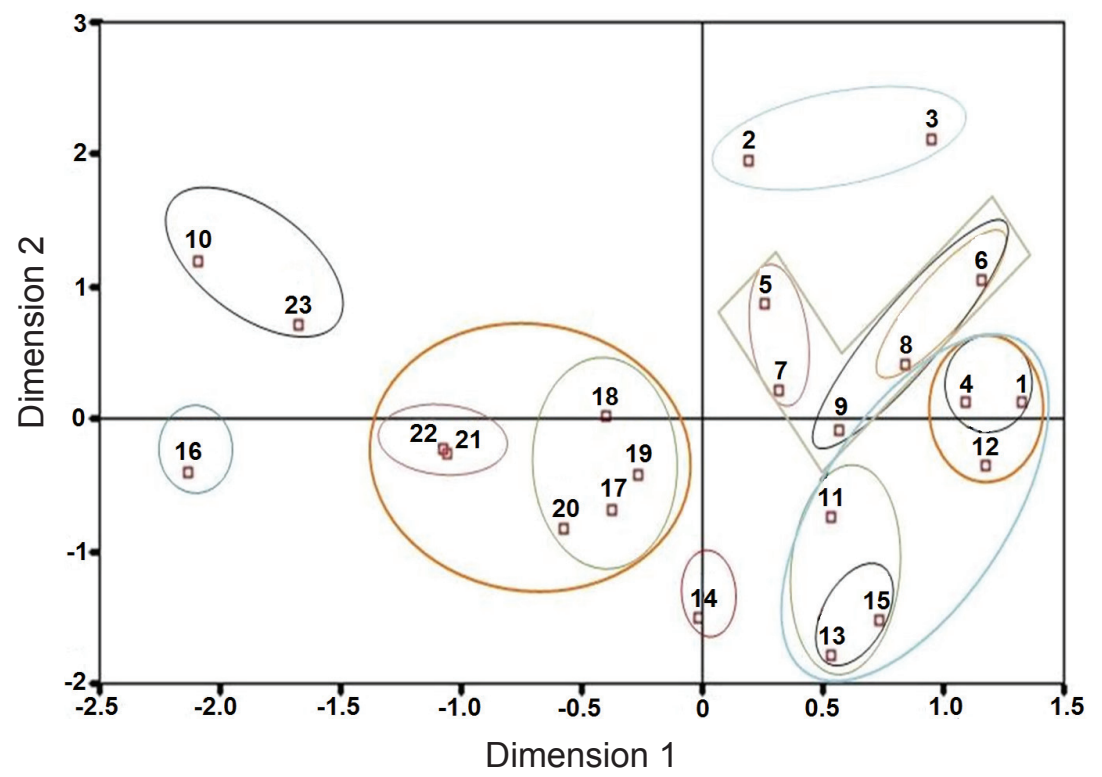

Fig. 4. Spatial distribution of different microsporidians infecting tasar silkworm, Antheraea mylitta, based on the ALSCAL multidimensional scaling method using Euclidean distance matrix. For the details on 1-23 microsporidian isolates, see Table 1.

reference strain Nosema bombycis maintained at Sericultural Experimentation Station, Tokyo, Japan with GenBank accession number D85503 (Table 1). Canning et al. (1999) suggested that determination of the status of other microsporidian isolates should be made against D85503. Hence, NIK-1s_mys was included as reference isolate/species in the present study for comparing new microsporidian isolates identified from A. mylitta. Several researchers used small differences in microsporidian spore size as an indication of the genus. However, these small differences in spore width and length alone should not be considered as a taxonomic character, as the spore size for a given species may vary with the host size (Brooks and Cranford 1972) and is affected by temperature (Maddox and Sprenkel 1978, Medeiros et al. 2004), age of the host and the medium in which they are measured (Malone and Wigley 1981, Mercer and Wigley 1987).

The occurrence of the spores of different microsporidians in the eggs was observed from 4th day of embryonic development onwards. Most of the microsporidian species are known to be transmitted both vertically, i.e. direct transfer of infection from parent to progeny, and horizontally, i.e. transmission of the pathogen from one individual to another of the same generation (Becnel and Andreadis 1999). Transovarial transmission or vertical transmission via the gametes among microsporidians has been reported by a number of researchers (Ishihara and Fujiwara 1965, Becnel et al. 1989, Dunn et al. 1998, Rao et al. 2007). Dunn et al. (1993) and Terry et al. (1997) felt that vertical transmission from generation to generation is crucial for the survival of the parasite within the host population.

The ISSR-PCR amplification patterns generated from the 23 microsporidian isolates revealed that each of the ISSR primers produced clear polymorphic banding patterns and delineated the isolates with good bootstrap confidence values from the reference strain (NIK-1s_mys). The dendrogram clearly revealed geographical clustering of 11 microsporidian isolates collected from Deoghar, East Singhbhum and West Singhbhum (Fig. 3). The other isolates were distributed randomly along with other microsporidian isolates from different geographical regions (Giridih, Ranchi, Dhanbad, Kharshawan, Dumka and Chaibasha). This type of random distribution may be due to the fact that seed cocoons were frequently transported from one place to another for rearing purpose. The dendrogram also places NIK-1s mys, along with MIJ-1kDm (Fig. 3), at a bootstrap value of $55 \%$, suggesting that MIJ-1 $\mathrm{kDm}$ is indeed similar to the reference strain, NIK-1s_mys.

Even the multidimensional scaling of the ISSR data, using the ALSCAL algorithm on Euclidean distance matrix, has clearly separated the microsporidians from each other and reference strain, NIK-1s_mys (Fig. 4). This method is expected to be more informative about differentiating distinct and closely related isolates. The use of pictorial representation of data using ALSCAL- multidimensional scaling has not only supported the information generated by the UPGMA dendrogram, but it has made the Euclidean distances among different microsporidians more clear. In both instances, the grouping was very similar and it is important to note that, the genetic distance values were used to construct dendrogram using the method of Nei and Li (1979), whereas the Euclidean method (Young et al. 1984, Young and Harris 1990) was used to obtain similarity matrix in ALSCAL-multidimensional scaling. The results from both methods gave similar patterns of grouping, discriminating the microsporidians isolated from A. mylitta from each other and from the reference strain (Figs. 3, 4).

Dinucleotide repeats $(\mathrm{AC})_{\mathrm{n}},(\mathrm{CA})_{\mathrm{n}},(\mathrm{GA})_{\mathrm{n}}$ and $(\mathrm{AG})_{\mathrm{n}}$ with a number of anchors, gave the best polymorphic and informative markers. Among the dinucleotide repeats observed in this study $(\mathrm{AC})_{\mathrm{n}}$ and $(\mathrm{CA})_{\mathrm{n}}$ were most prevalent in the genome of different microsporidian isolates infecting A. mylitta. Few trinucleotide repeats (AGC), $)_{n}(\mathrm{ATG})_{\mathrm{n}}$ and one pentanucleotide repeat (GGGTG) also produced 
informative banding patterns. The ISSR fingerprinting results of Rao et al. (2005) showed that the dinucleotide $(\mathrm{AG})_{\mathrm{n}},(\mathrm{GT})_{\mathrm{n}}$ and trinuclotide repeats $(\mathrm{ATG})_{\mathrm{n}},(\mathrm{CTC})_{\mathrm{n}}$, $(\mathrm{GTT})_{\mathrm{n}}$ were most abundant in the genome of different microsporidian species isolated from the mulberry silkworm, Bombyx mori. Based on the di- and tri- nucleotide amplification results, it is clear that the different microsporidian isolates identified from the tasar silkworm are different from the microsporidians identified from mulberry silkworms. In agreement with other studies, both di-, and trinucleotide repeats were very useful to amplify polymorphic bands (Fang et al. 1997, Nagaoka and Ogihara 1997, Blair et al. 1999, Reddy et al. 1999, Rao et al. 2005).

ISSR profiles in the present study clearly delineated 22 microsporidian isolates from $A$. mylitta with good bootstrap confidence values from reference strain, NIK-1s_mys confirming the capability of ISSR markers to discriminate different microsporidian isolates (Fig. 3). On the basis of the ISSR-PCR results, it is clear that NIK-1s_mys is similar to MIJ-1kDm, and remaining 21 microsporidian isolates could be different species. Thus, the present study is the first report on identification and discrimination of microsporidian isolates from tropical tasar silkworm, A. mylitta, based on ISSR-PCR strategy. The study confirms that molecular tools, i.e. ISSR-PCR analysis, is an alternative and facilitates more useful genetic diversity studies of different microsporidians infecting various hosts. This technique requires only a small amount of genomic DNA and can produce high levels of polymorphism.

In conclusion, it is inferred that all the 22 microsporidians identified from the tasar silkworm differed in their ISSR profiles indicating genetic variability. ISSR-PCR is one of the simplest and quickest marker systems with high reproducibility, including the virtue of its unique efficiency in distinguishing even closely related organisms; it may be important for proper identification of different species of microsporidian. It is evident that ISSR primers could detect more polymorphism than RAPD, RFLP and isozyme analysis in closely related organisms (Salimath et al. 1995, Shivaji et al. 2000, Rao et al. 2005, Vijayan 2005, Kumar et al. 2007). The high level of polymorphism realised from this study further proves the efficacy of ISSR technique.

Acknowledgements. The authors are grateful to Department of Biotechnology, Government of India for financial support. Wazid Hassan is a recipient of Research Fellowship by DBT and University Grants Commission (Maulana Azad National Fellowship).

\section{REFERENCES}

Becnel J.J., Andreadis T.G. 1999: Microsporidia in insects. In: W. Murray and M.W. Louis (Eds.), The Microsporidia and Microsporidiosis. American Society of Microbiology, Washington, DC, pp. 447-501.

Becnel J.J., Sprague V., Fukuda T., Hazard E.I. 1989: Development of Edhazardia aedes (Kudo, 1930) n.g., n. comb (Microsporidia: Amblyosporidae) in the mosquito Aedes aegypti (L) (Diptera: Culicidae). J. Protozool. 3: 119-130.

Blair M.W., Panaud O., Mccouch S.R. 1999: Inter simple sequence repeat (ISSR) amplification for analysis of microsatellite motif frequency and fingerprinting in rice (Oryza sativa L.) Theor. Appl. Genet. 98: 780-792.

Brooks W.M., Cranford J.D. 1972: Microsporidoses of the hymenopterous parasites, Campoletis sonorensis and Cardiochiles nigriceps, larval parasites of Heliothis species. J. Invertebr. Pathol. 20: 77-94.

Canning E.U., Curry A., Cheney S.A., Lafranchi-Tristem N.J., Kawakami Y., Hatakeyama Y., Iwano H., Ishihara R. 1999: Nosema tyriae n. sp. and Nosema sp., microsporidian parasites of cinnabar moth Tyria jacobaeae. J. Invertebr. Pathol. 74: 29-38.

Chakrabarti S., Manna B. 2008: Studies on cross-inection of microsporidian spores of mulberry, eri and muga silkworms to tasar silkworm, Antheraea mylitta $\mathrm{D}$. and its impact on economic parameters. Ind. J. Seric. 47: 94-100.

DicE L.R. 1945: Measures of the amount of ecological association between species. Ecology 26: 297-302.

Dunn A.M., Adams J., Smith J.E. 1993: Transovarial transmission and sex ratio distortion by a microsporidian parasite in a shrimp. J. Invertebr. Pathol. 61: 248-252.

Dunn A.M., Terry R.S., Taneyhill D.E. 1998: Within-host transmission strategies of transovarial, feminizing parasites of Gammarus duebeni. Parasitology 117: 21-30.

Dutta S.R., Kar P.K., Srivastava A.K., Sinha M.K., Shankar J., GHosh A.K. 2012: Identification of RAPD and SCAR markers associated with yield traits in the Indian tropical tasar silkworm Antheraea mylitta drury. Genet. Mol. Biol. 35: 743-751.

Fang D.Q., Roose M.L., Krueger R.R., Federici C.T. 1997: Fingerprinting trifoliate orange germ plasm accessions with iso- zymes, RFLPs and inter-simple sequence repeat markers. Theor. Appl. Genet. 95: 211-219.

Field D., Wills C. 1996: Long polymorphic microsatellites in simple organisms. Proc. R. Soc. B. 263: 209-215.

Gur-Arie R., Cohen C.J., Eitan Y., Shelef L., Hallerman E.M., Kashi Y. 2000: Simple sequence repeats in Escherichia coli: abundance, distribution, composition and polymorphism. Genome Res. 10: 62-71.

Hatakeyama Y., Bansal A.K., Iwano H., Kawakami Y., IshiHARA R. 2000: Characterisation of SSU rRNA sequence of a new microsporiium Nosema sp. (Nosematidae: Microsporidia) isolated from Antheraea mylitta Drury (Lepidoptera: Saturnidae) in India. Ind. J. Seric. 39: 131-134.

ISHIHARA R., FUJIWARA T. 1965: The spread of pebrine within a colony of silkworm, Bombyx mori. J. Invertebr. Pathol. 7: 126131.

Keeling P. 2009: Five questions about microsporidia. Plos. Pathol. 5: e1000489.

Kumar A.R., Sathish V., Nair G.B., Nagaraju J. 2007: Genetic characterization of Vibrio cholerae strains by inter simple sequence repeat-PCR. FEMS. Microbiol. Lett. 272: 251-258.

Maddox J.V., Sprenkel R.K. 1978: Some enigmatic microsporidia of the genus Nosema. Misc. Publ. Entomol. Soc. Am. 11: $65-84$.

Malone L.A., Wigley P.J. 1981: The morphology and development of Nosema carpocapsae, a microsporidian pathogen of the codling moth, Cydia pomonella (Lepidoptera: Tortricidae) in New Zealand. J. Invertebr. Pathol. 38: 315-329.

Medeiros J., Tavares J., Simoes N., Solter L.F. 2004: A new isolate of the microsporidium Vairimorpha necatrix (Microsporidia: Burenellidae) recorded in the Azores. J. Invertebr. Pathol. 85: 58-60.

Mercer C.F., Wigley P.J. 1987: A microsporidian pathogen of the poroporo stem borer, Sceliodes cordalis (Dbld.) (Lepidoptera: Pyralidae). J. Invertebr. Pathol. 49: 93-101.

Moore S.S., Sargeant L.L., King T.J., Mattick J.S., George M., Hetzel D.J.S. 1991: The conservation of dinucleotide microsatellites among mammalian genomes allow the use of heter- 
ologous PCR primer pairs in closely related species. Genomics 10: 654-660.

Nagaoka T., Oghinara Y. 1997: Applicability of inter-simple sequence repeat polymorphism in wheat for use as DNA markers in comparison to RFLP and RAPD markers. Theor. Appl. Genet. 94: 597-602.

Nath B.S., Hassan W., Rao S.N., Prakash N.B.V., Gupta S.K., Mohanan N.M., BajPai A.K. 2011: Genetic diversity among microsporidian isolates from the silkworm, Bombyx mori, as revealed by randomly amplified polymorphic DNA (RAPD) markers. Acta Parasitol. 56: 333-338.

NeI M., Li W.H. 1979: Mathematical model for studying genetic variation in terms of restriction endonucleases. Proc. Natl. Acad. Sci. USA 76: 5269-5273.

Rao S.N., Nath B.S., Bhuvaneswari G., Urs R.S. 2007: Genetic diversity and phylogenetic relationships among microsporidia infecting the silkworm, Bombyx mori, using random amplification of polymorphic DNA: morphological and ultrastructural characterization. J. Invertebr. Pathol. 96: 193-204.

Rao S.N., Nath B.S., Saratchandra B. 2005: Characterization and phylogenetic relationships among microsporidia infecting silkworm, Bombyx mori, using inter simple sequence repeat (ISSR) and small subunit rRNA (SSU-rRNA) sequence analysis. Genome 48: 355-366.

Reddy K.D., Nagaraju J., Abraham E.G. 1999: Genetic characterization of the silkworm, Bombyx mori by simple sequence repeat (SSR)- anchored PCR. Heredity 83: 681-687.

Salimath S.S., De Oliveira A.E., Godwin J.D., Bennetzen J.L. 1995: Assessment of genome origins and genetic diversity in the genus Eleusine with DNA markers. Genome 38: 757-763.

SambrooK J., Fritsch E.F., Maniatis T. 1989: Molecular Cloning: a Laboratory Manual. Second Edition. Cold Spring Harbor Laboratory, Cold Spring Harbor, New York.

Shivaji S., Bhanu N.V., Aggarwal R.K. 2000: Identification of Yersinia pestis as the causative organism of plague in India as determined by $16 \mathrm{~S}$ rDNA sequencing and RAPD-based genomic fingerprinting. FEMS. Microbiol. Lett. 189: 247-252.

Singh G.P., Kumar K.P.K., Sinha A.K., Prasad B.C. 2011: Manual on Management of Diseases in Tasar Silkworm. CTRTI, Ranchi, 96 pp.

Terry R.S., Dunn A.M., Smith J.E. 1997: Cellular distribution of a feminizing microsporidian parasite: a strategy for trasovarial transmission. Parasitology 115: 157-163.
Undeen A.H., Alger N.E. 1971: A density gradient method for fractionating microsporidian spores. J. Invertebr. Pathol. 18: 419-420.

Undeen A.H., Cockburn A.F. 1989: The extraction of DNA from microsporidian spores. J. Invertebr. Pathol. 54: 132-133.

UndeEN A.H., VÁVRA J. 1997: Research methods for entomopathogenic protozoa. In: L.A. Lacey (Ed.), Manual of Techniques in Insect Pathology, Academic Press, San Diego, pp. 117-151.

Vijayan K., Nair C.V., Kar P.K., Mohandas T.P., SaratchanDRA B., URS S.R. 2005: Genetic variability within and among three ecoraces of the tasar silkworm Antheraea mylitta Drury, as revealed by ISSR and RAPD Markers. Int. J. Indust. Entomol. 10: $51-59$.

Vossbrinck C.R., Maddox J.V., Friedman S., DebrunnerVossbrinck B.A., Woese C. R. 1987: Ribosomal RNA sequence suggests microsporidia are extremely ancient eukaryotes. Nature 326: 411-414.

Vossbrinck C.R., Woese C.R. 1986: Eukaryotic ribosomes that lack a 5.8S RNA. Nature 320: 287-288.

Wasson K., Peper R.L. 2000: Mammalian microsporidiosis. Vet. Pathol. 37: 113-128.

WeIss L.M. 2001: Microsporidia 2001: Cincinnati. J. Eukaryot. Microbiol. S: 47S-49S.

Williams J.G.K., Kubelik A.R., LivaK K.J., Rafalski J.A., TINGEY S.V. 1990: DNA polymorphisms amplified by arbitrary primers are useful as genetic markers. Nucl. Acids. Res. 18: 6531- 6535 .

Wittner M., Weiss L.M. 1999: The Microsporidia and Microsporidiosis. ASM Press, Washington, D.C., 553 pp.

YAP I.V., NeLSON R.J. 1996: WINBOOT: a program for performing bootstrap analysis of binary data to determine the confidence limits of UPGMA-based dendrograms. IRRI discussion paper series No. 14, International Rice Research Institute, Manila, 32 pp.

Young F.W., Easterling D.V., Forsyth B.N. 1984: The general Euclidean model for scaling three mode dissimilarities: theory and allocation. In: H.G. Law, G.W. Snyder Jr., J. Hattie, R.P. McDonald (Eds.), Research Methods for Multi-mode Data Analysis in the Behavioural Sciences. Praeger, New York.

Young F.W., HARRIS D.F. 1990: Multidimensional scaling: procedure ALSCAL. In: M. Norusis (Ed.), SPSS Base System: User's Guide, Chicago, pp. 397-461.

Zietkiewicz E., Rafalski A., Labuda D. 1994: Genome fingerprinting by simple-sequence repeat (SSR)-anchored polymerase chain reaction amplification. Genomics 20: 176-183. 